\title{
Governance Network Theory Re-examined: Implications of the Research Findings of the Water and Sanitation Sector Governance Network of the Municipality of Tela, Honduras
}

\author{
Alvarado Rigoberto Edgardo \\ School of Urban Planning, McGill University, Montreal H3A0C2, Canada
}

Corresponding Author Email: rigoberto.alvarado@ mail.mcgill.ca

https://doi.org/10.18280/ijsdp.160304

Received: 15 July 2020

Accepted: 8 December 2020

\section{Keywords:}

governance network theory, indifference, social drivers, social exclusion, societal governance

\begin{abstract}
A water and sanitation sector governance network was researched to determine the social and governance drivers present in the case study area. This paper presents evidence of these drivers that underpin the institutional theoretical approach to the study of governance networks. Evidence suggests that the social drivers calculation and culture are present in the case study area; likewise, the governance drivers conflict and coordination are also present. The findings also suggest that indifference, as a form of societal governance, is also present in the research site and is a driver unexplored in the existing governance network theoretical framework. Consequently, it is suggested that network governance theory could be strengthened by the incorporation of this form of societal governance. Researchers wishing to explore new frontiers can explore the driver indifference in governance network theory, as its negative impacts likely undermine the efficiency and general operations of governance networks, especially in regions or countries where patronage politics has a predatory control over a majority of resources.
\end{abstract}

\section{INTRODUCTION}

Governments worldwide supply water and sanitation services through traditional, formal government institutions and, increasingly, through networks and partnerships. These networks involve diverse local, national and international actors that channel significant quantities of development resources, thereby the value of monitoring their efficiency has been recognized, as periodic evaluations by governments or civil society could likely accelerate and improve the effectiveness of service provision. However, a literature review revealed that Water and Sanitation Sector (WSS) governance networks are rarely evaluated, in part because assessment approaches are well known and established for traditional project, program or institutional service provision, but not well established for network and partnerships [1].

Acknowledging these limitations, the first objective of our research was to develop and apply a new approach to the assessment of network governance. The results of this work include a proposed new analytical framework that was published in 2018 [2]. "The approach is both theoreticalconceptual, drawing on existing literature on governance network theory to design an evaluation framework around the policy cycle, and empirical in that the specific performance indicators were customized to the local context where the evaluation approach was tested" [2]. Our case study setting was Tela, a medium-size municipality located on the Atlantic coast of Honduras, where network governance in the water and sanitation sector has become increasingly prevalent over the past decade.

The second objective of our research, the results of which are presented in this article was to obtain empirical information about the social and governance drivers found in the case study from the perspective of governance network theory, research that is especially important as few studies provide empirical evidence of the drivers that underpin network theory within the context of developing countries. Furthermore, our research suggests the presence of indifference as a governance driver a factor not previously considered by the network theory framework. This article is presented in six parts: This introduction, a brief review of governance network theory, the research methods employed and the study area, the empirical evidence $\&$ analysis, an analysis of indifference as related to governance network theory, and a summary of research findings.

\section{GOVERNANCE NETWORK THEORY}

Network governance is defined as a distinct mode of coordinating economic, social, and political activity by a large number of interdependent actors who interact, informally or formally, to accomplish joint goals. Networks are frequently formed among government organizations, the private sector, and NGO associations as a means to seek solutions to specific issues as well as to create opportunities for joint collaborative development.

Networks can have a vertical and/or horizontal structure. Vertical relations are mainly observed between different levels of government departments at local, regional, and national levels while horizontal networks are formed between various agencies organized at the same level [3]. There can be many different types of networks, such as policy, planning, and/or action networks and they are increasingly being used to address complex interrelated problems that require collective, multidisciplinary, multi-scalar, and multiregional stakeholder 
participation, resource sharing, and joint learning processes [4].

Table 1. Overview of four different governance network theories

\begin{tabular}{|c|c|c|}
\hline & Calculation & Culture \\
\hline \multirow{2}{*}{ Conflict } & Interdependency & Governmentality \\
& Theory $[5,6]$ & Theory $[7,8]$ \\
\hline \multirow{2}{*}{ Coordination } & Governability & Integration theory \\
& Theory $[9,10]$ & {$[11,12]$} \\
\hline
\end{tabular}

Source: (15)

Table 2. Some definitions applicable to network theory (The $4 \mathrm{C}$ framework)

\begin{tabular}{|c|c|}
\hline \multicolumn{2}{|c|}{ Social Drivers (Driving forces of social action) } \\
\hline Calculation & $\begin{array}{l}\text { Self-driven individual calculation of costs } \\
\text { and benefits }\end{array}$ \\
\hline Culture & $\begin{array}{l}\text { Rules, norms, and values intrinsic to the } \\
\text { culture }\end{array}$ \\
\hline \multicolumn{2}{|c|}{ Governance Drivers (Defining features of societal governance) } \\
\hline Conflict & $\begin{array}{c}\text { Power struggles and conflicts as a defining } \\
\text { feature of societal governance }\end{array}$ \\
\hline Coordination & $\begin{array}{l}\text { Harmonious interaction for joint goal } \\
\text { attainment based on mutual trust and } \\
\text { institutional rules }\end{array}$ \\
\hline
\end{tabular}

Note: Definitions based on Sorensen's and Torfing's consolidated vision of network theory.

Table 3. Four governance network theories and their characteristics

\begin{tabular}{|c|c|}
\hline $\begin{array}{c}\text { Governance } \\
\text { Network Theory }\end{array}$ & Characteristics \\
\hline $\begin{array}{c}\text { Interdependence } \\
\text { Theory }\end{array}$ & $\begin{array}{l}\text { It defines governance networks as a } \\
\text { mechanism for negotiation based on } \\
\text { common understanding between } \\
\text { interdependent, but conflicting actors } \\
\text { each of whom has a rule and resource } \\
\text { base of their own. This theoretical } \\
\text { approach contributes insight into conflict } \\
\text { resolution. }\end{array}$ \\
\hline $\begin{array}{c}\text { Governability } \\
\text { Theory }\end{array}$ & $\begin{array}{l}\text { Governance networks are formed through } \\
\text { the construction of game-like situations } \\
\text { that enhance horizontal coordination. } \\
\text { They are held together partly by } \\
\text { anticipated joint gains from resource } \\
\text { pooling. This theoretical approach } \\
\text { contributes insight into a win-win } \\
\text { scenario. }\end{array}$ \\
\hline $\begin{array}{c}\text { Governmentality } \\
\text { Theory }\end{array}$ & $\begin{array}{l}\text { Governmentality theory is not a network } \\
\text { theory per se, and it does not have any } \\
\text { clear definition of governance networks. } \\
\text { However, it implicitly conceives } \\
\text { governance networks as a reflective } \\
\text { attempt to facilitate the mobilization and } \\
\text { shaping of free actions of self-governing } \\
\text { actors. Contributes insight into conflict } \\
\text { resolution. }\end{array}$ \\
\hline $\begin{array}{l}\text { Integration } \\
\text { Theory }\end{array}$ & $\begin{array}{l}\text { It defines governance networks as a } \\
\text { relatively institutionalized platform for } \\
\text { the interaction of relevant and affected } \\
\text { actors that are integrated into a } \\
\text { community that has common norms and } \\
\text { perceptions. Contributes insight for a } \\
\text { holistic approach to development. }\end{array}$ \\
\hline
\end{tabular}

Note: Prepared based on theoretical framework presented by Sorensen and Torfing [13].
Governance network theorists indicate that four theoretical positions that draw on institutional approaches underpin the operation and performance of the governance networks [14, 15]. Specifically, governance network theories are categorized into four types that differ in two important dimensions. First, network theories differ according to whether rational calculation or culture-bound rules are seen as the driving force of social action. Calculation is understood as individual decisions rooted in self-interest based on costs and benefits. Culture is taken as the norms and intrinsic values that shape a particular culture. Second, they differ according to whether they perceive conflict or smooth coordination as the defining feature of societal governance. Table 1 shows an overview of these four theoretical approaches according to the analytical distinctions calculation-culture versus conflict-coordination and Table 2 presents simplified definitions for each of the drivers.

According to Sorensen and Torfing, these theoretical positions are an attempt to provide a central reference for future research and an attempt to simplify the complex theoretical terrain. Although it has been reported that interdependency theory and governability theory are the two main approaches in the study of governance networks [6].

Table 3 illustrates important characteristics that differentiate the theoretical approaches. These theoretical approaches have the strength of providing a sense of order in the otherwise very complex terrain of governance network theory. Consequently, studies were conducted in the Region of Tela, Honduras to research if the proposed conceptual framework is supported by empirical evidence. The methods used to gather the empirical evidence follow.

\section{METHODS AND CASE STUDY AREA}

Governance network theory acknowledges that the social drivers (Calculation and Culture) and the governance drivers (Conflict and Coordination) given in Table 1 underpin networks. Hence to further understand network theory and its drivers, the WSS governance network of the Municipality of Tela was selected as a case study.

This municipality located on the Atlantic coast of Honduras has 87,643 inhabitants of which 45,333 live in urban areas $(52 \%)$ and 42,110 dwell in the rural area $(48 \%)$ distributed among 76 villages and 263 communities. Its major city Tela is representative of a Honduran medium-size city [16].

Approximately nine months of fieldwork were completed in Honduras between July 20 - Nov 17, 2011, and June 5 to October 19, 2012. Data Collection for this research - which centered on water and sanitation governance - included the analysis of annual institutional reports, project completion reports, progress reports, minutes of meetings, and letters of the various stakeholders of the network. A participatory observation process also made available miscellaneous inhouse memoranda.

A total of 26 non-structured interviews were done with (a) randomly-selected people at the Central Park of the City of Tela and (b) employees of the tourism sector to obtain qualitative feedback about the prevailing social and governance drivers. Respondents were asked the following open question: What are the most important environmental and social problems that are affecting the development of Tela?

Likewise, 44 semi-structured interviews were also 
conducted with managers and personnel working in the Water and Sanitation Sector of the Municipality of Tela. The purpose of the research was explained to each person interviewed and all - agreed to participate as they understood that the findings could provide insight to improve and expand water and sanitation service in the Country. Key informant interviews were conducted at various levels of government towards determining the efficiency of the WSS governance network and to obtain feedback about the prevailing social and governance drivers in the region. Respondents were asked basic questions relevant to the environmental and social problems affecting the water and sanitation sector of Tela.

\section{EMPIRICAL EVIDENCE AND ANALYSIS}

The eight stakeholders listed in Table 4 illustrated as a multi-level network in Figure 1 constitute the WSS governance network of the Municipality of Tela and this research suggests that the social and governance drivers in Sorensen's and Torfing's mapping of the theoretical terrain are observable in the case study area. A discussion of the social drivers calculation \& culture and the governance drivers conflict \& coordination follows:

Calculation - taken as each person trying to make a profit or "get ahead" - is a dominant social force in the region, possibly influenced by the prevailing capitalist economic model followed by the country. For example, calculation was found present at the small retailer "pulperia" that sell candy or sodas to pedestrians, at the large gated hotels that handle most international tourists, and within political patronage networks working to maximize the benefits to its members, rather than the benefit of society at large.

Culture was found present in the form of established rules, norms, and accepted customary practices that affect daily life, politics, and network forms of governance. Culture in its popular meaning, as associated with the music, foods, religious beliefs, dances, and the like, is not the focus of the network governance approach, except as it affects the values, institutional structures (from household leaders to organizations empowered to make decisions), and social relations entwined with governance. Such cultural elements may have positive or negative effects on governance. For example, positive cultural issues such as strong comradery, trust, and ongoing commitment were identified in segments of the WSS governance network in Tela, notwithstanding negative cultural issues such as mistrust and corruption were also identified. A reliance on face-to-face communication and personal ties appear to contribute to strong trust among the local members of the governance network while a lack of ethics such as the "usurpation and purchase of public post for the exclusive purpose of personal enrichment" appears to catalyze corruption. Empirical evidence also suggests that cultural drivers such as racial discrimination [17], the culture of the turf [18], and patronage politics $[19,20]$ are negatively affecting the different cultural communities that co-exist in the region as well as efforts at governance, whether of network or other types.
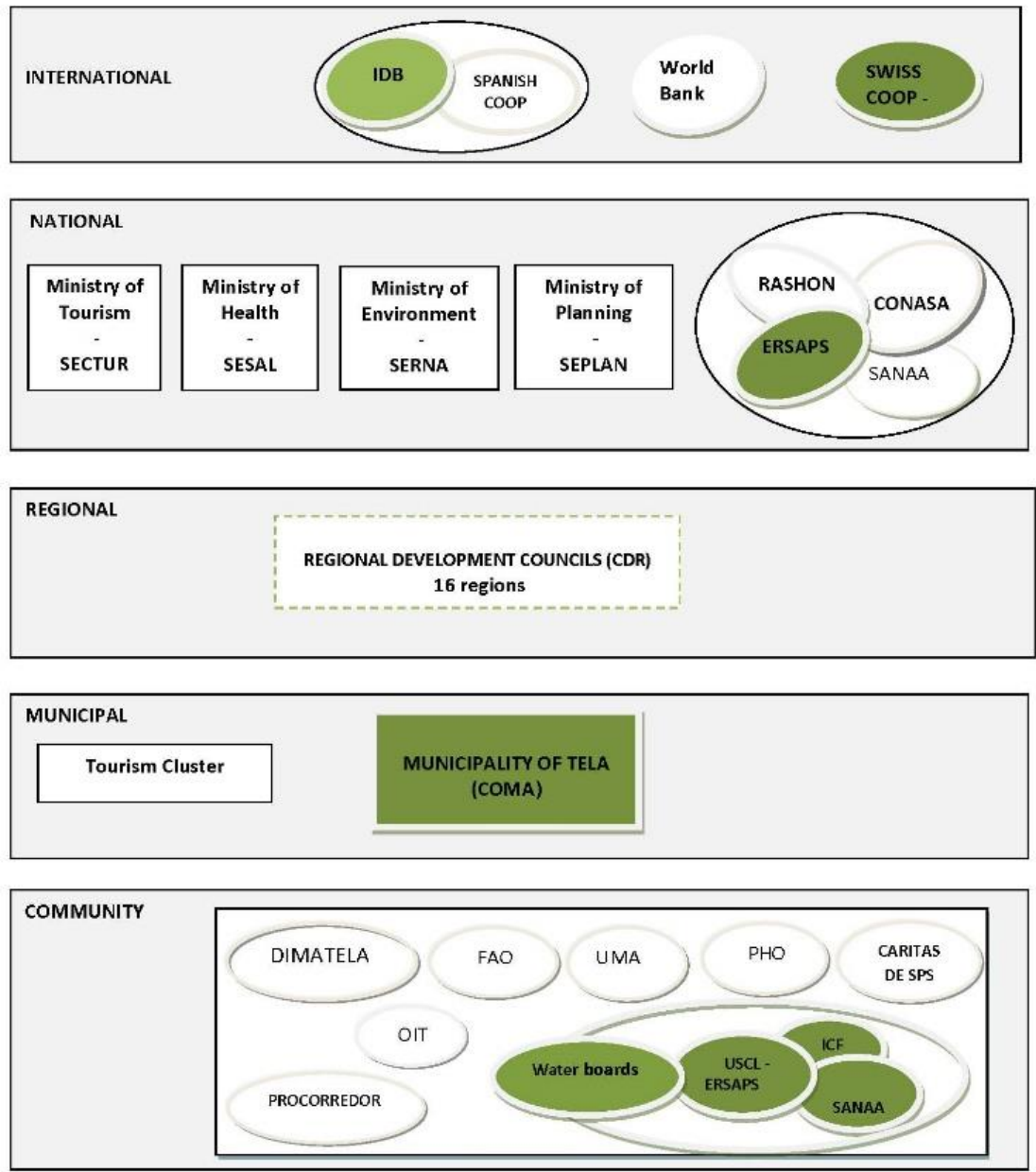

Note 1: Stakeholders of the network are illustrated in green.

Figure 1. Multi-level conformation in the WSS governance network - Tela 2012 (Source: Author) 
Table 4. A water and sanitation governance network at the municipality of Tela

\begin{tabular}{|c|c|}
\hline $\begin{array}{c}\text { National } \\
\text { Institutions }\end{array}$ & International Organizations \\
\hline Advisory Municipal Committee of Water and Sanitation (COMA - Tela) & $\begin{array}{l}\text { Inter-American Development Bank } \\
\text { (IDB - Spanish Cooperation) }\end{array}$ \\
\hline $\begin{array}{l}\text { Unit of Local Supervision and Control } \\
\text { (USCL/ERSAPS -Tela office) }\end{array}$ & $\begin{array}{l}\text { Swiss Cooperation for Development (SCD- } \\
\text { COSUDE) }\end{array}$ \\
\hline \multicolumn{2}{|l|}{ National Institute of Forest Conservation and Development (ICF - Tela Office) } \\
\hline \multicolumn{2}{|l|}{$\begin{array}{l}\text { National Autonomous Service of Water and Sewage - (SANAA - Regional office of } \\
\text { La Ceiba) }\end{array}$} \\
\hline \multicolumn{2}{|l|}{ Regulatory Entity of Water Supply and Sanitation (ERSAPS - National level) } \\
\hline $\begin{array}{c}\text { Water boards - Owners of the community water systems - } 48 \text { located in the } \\
\text { Municipality }\end{array}$ & \\
\hline
\end{tabular}

Note 1: WSS governance network terrain as seen in 2012 -Source Author

Table 5. Social and governance drivers evident in the study area -From non-structured interviews at Central Park and Employees of the Tourism Sector

\begin{tabular}{|c|c|}
\hline Source of Information & Examples of Comments \\
\hline $\begin{array}{l}\text { Non-structured casual interviews with } \\
\text { a) Randomly selected persons at the } \\
\text { Central Park of the City of Tela } \\
\text { b) Employees of the tourism sector }\end{array}$ & $\begin{array}{l}\text { - Little to no coordination among responsible organizations such as the Municipality, } \\
\text { - Thamber of Tourism, Chamber of Commerce, Municipal office of tourism, etc. } \\
\text { - } \quad \text { The Municipality is divorced from the Chamber of Tourism and the Chamber of Commerce. } \\
\text { - No cooperation among hotels. Every person for him or herself. } \\
\text { - The attitude of the leaders of our municipality needs a drastic change. } \\
\text { - The attitude of people living in Tela. } \\
\text { - Mayor of Tela indifferent to Teleños. } \\
\text { - } \text { pity in a state of total neglect. Avenues, sidewalks, green areas, and important entrance } \\
\text { - The Mayor of Tela is not concerned with the City. } \\
\text { The unwillingness of the local administration for Tela to develop a touristic vision. }\end{array}$ \\
\hline
\end{tabular}

Source: Author

Table 6. Social and governance drivers evident in the study area- From semi-structured interviews to WSS governance network -Municipality of Tela

\begin{tabular}{|c|c|}
\hline Source of Information & Examples of Comments \\
\hline $\begin{array}{l}\text { Semi-structured interviews with managers and } \\
\text { personnel of the eight stakeholders that are part of the } \\
\text { WSS governance network of the Municipality of Tela }\end{array}$ & $\begin{array}{l}\text { - } \quad \text { Personal interest prevails over the needs of the community. } \\
\text { - } \quad \text { Local government only thinks of winning the next elections. } \\
\text { - Thicipal budgets are openly used for political purposes. } \\
\text { - } \quad \text { Municipor has too much power, the law of Municipalities should be reformed } \\
\text { the population. } \\
\text { - There is no political will to solve the water problem of the City of Tela. } \\
\text { - } \text { Poor water quality causes the death of children, the municipality is partially } \\
\text { - The sanitation systems of the City of Tela is awful. } \\
\text { - The water municipal authority of the City of Tela (DIMATELA) must be } \\
\text { decentralized but there is no political will. It is a very profitable Department, } \\
\text { and its funds are used for other purposes not related to water and sanitation. } \\
\text { DIMATELA is not complying with } 60 \% \text { of its functions and responsibilities. } \\
\text { Advisory Municipal Committee of Water and Sanitation (COMAS) responds } \\
\text { only to the interest of the Major. }\end{array}$ \\
\hline
\end{tabular}

Table 7. Social and governance drivers evident in the study area - Participatory Observation

\begin{tabular}{|c|ll|}
\hline Source of Information & \multicolumn{1}{c|}{ Observations } \\
\hline & $\bullet$ & $\begin{array}{l}\text { Mayor never or rarely visits communities. } \\
\text { Participatory Observation } \\
\text { Two residence periods at USCL - } \\
\text { Tela Office }\end{array}$ \\
& $\bullet \begin{array}{l}\text { No links between Chamber of Commerce and Chamber of Tourism, but both groups accept the } \\
\text { Peaceful co-existence between ladinos and blacks but no real integration. } \\
\text { Of the fifty-five (55) e-mails sent about this research, only 7 responses were received, of which } \\
5 \text { were from expatriates. } \\
\text { None or small numbers of Garifunas work for the Municipal Corporation, although a few were } \\
\text { found working in hotels. }\end{array}$ \\
\hline
\end{tabular}


The governance drivers of conflict and coordination are also distinguishable in the Tela WSS governance network (Table 2). Conflicts appear negligible in the rural Water Sanitation Sector, but strong conflicts exist related to coastal land tenure for tourism development [21, 22]. Concerning coordination, strong levels were found in the WSS governance network that was evaluated, but there is a lack of coordination between urban and rural water and sanitation service provision. Likewise, there is no apparent coordination between the public and private sectors for the planning, management, development of water resources and sanitation.

Hence, interviews and participatory observation suggest that the four social and governance drivers, of Sorensen's and Torfing's theoretical framework, are present in the region, which validates their theoretical proposal. Nonetheless, the framework appears incomplete; interviews in the City of Tela also suggest that local authorities, both public and private, manage their affairs with a good dosage of indifference towards the population at large. For example, in interviews with a randomly selected people at the Central Park of the City Tela, in 2011, respondents made comments like "the mayor of Tela is indifferent with Teleños" and "the Municipality is divorced from the Chamber of Tourism and the Chamber of Commerce" Examples of other comments are given in Table 5.

Furthermore, semi-structured interviews conducted in 2012 with managers and personnel of the eight stakeholders that are part of the WSS governance network of the Municipality of Tela (Table 4) also insinuate that local authorities manage their affairs with a good dosage of indifference towards the population at large. For example, respondents made comments such as "Municipal government and private sector are both indifferent to the needs of the population" and "There is no political will to solve the water problem of the City of Tela" Examples of other comments are given in Table 6.

Besides, two participatory observation periods in the case study area also indicate that public and private authorities manage some of their affairs with indifference towards the population at large. For example, it was determined that the Mayor never or rarely visits the communities and that there are no formal direct links between the Chamber of Commerce and the Chamber of Tourism, but both groups accept the situation (Table 7). This qualitative research suggests that indifference as a societal governance driver is operating in the study area and that it operates for the benefit of family and friends of elected officials, at the expense of outsiders, namely the population at large. Furthermore, the document search suggests the governance driver of indifference is also deeply rooted in the Honduras public sector at large. For example, a comparative review of the performance of public administration completed for 22 countries of Central America and the Caribbean, evaluating the hiring processes of civil servants based on a merit indicator established that the Honduran merit indicator was only $8 \%$ [23], the lowest value of any country. Such results reflect the absence of procedures to prevent arbitrary personal and party interests from overwhelming those of the organization. Furthermore, the study indicates that in Honduras there is a lack of performance evaluation of civil servants. In contrast, the merit indicator of Costa Rica is $61 \%$, the highest in the region. Thus the empirical data obtained in the case study area suggest that government and private sectors are indifferent to the needs of the population; thereby it is suggested that "indifference" is a governance driver in the region. A discussion of the implications of this driver concerning Governance Network Theory follows.

\section{INDIFFERENCE AND GOVERNANCE NETWORK THEORY}

It is suggested that indifference as a societal governance force is present in the case study area, but this driver is not explicitly represented in the 'four theory' governance network framework (Table 1). How does this force affect the theoretical terrain? To approximate an answer, it is necessary to understand that indifference is literally the absence of both conflict and coordination. In this situation, the governance force of indifference has no intent; it is simple and pure indifference. This governance force can be present in all regions of the world. For example, in Germany, families living in poverty were described as a result of political and economic indifference [24]. Likewise in Niger, communities live under the impression that official voices do not pay attention to them, what they aspire or what happens to them, despite that they live only a few kilometers from Iferouane, a government administrative center in the northern region of the country [25]. These examples indicate that indifference cannot be taken as a lack of coordination as the latter has intent and purpose, while indifference has none. Indifference, at the individual level, can be defined for example, as disinterest in going to a party, to the daily weather, or voting in the next municipal election. In contrast to this popular definition, in this work indifference means that governance actors - whether formal organizations, government officials, or independent residents in the area - do not care enough about either the political and social processes or the potential outcomes to prompt action. In the examples from Tela cited above, government officials simply did not perform their mandated responsibilities, a behavior that is arguably rooted in indifference.

Thus, indifference, from the perspective of this research, is conceptualized as more than the sum of individual attitudes; it constitutes a governance driver like the others given in Tables 1. Moreover, the inclusion of this driver does not invalidate Sorensen and Torfing's governance network framework. On the contrary, the acknowledgment of indifference as a societal governance driver complements and expands the theoretical terrain.

The incorporation of indifference as a societal governance driver changes the theoretical framework, by giving rise to two new sets of drivers in the matrix, namely (CalculationIndifference) and (Culture-Indifference). The former appears to be closely linked to Social Exclusion Theory and the latter related to theories of Multi-cultural Peaceful Co-existence (Table 8).

But what are the social outputs of Calculation-Indifference? Empirical findings indicate that traditional Garifuna and Ladino cultures present in the region co-exist within a context of visible and powerful local patronage networks which, driven by calculation, target the expansion of turf. This type of patronage, when combined with indifference, produces a form of leadership centered on securing one's benefit with little interest in community goals and the public good. The duo calculation and indifference, in this case, leads to societal biases that exclude the poor (namely, ladinos and blacks) from mainstream development processes as well as from the benefits of good quality water, adequate quantities of water and adequate sanitation. Hence theory suggests that the set of 
drivers 'Calculation-Indifference' fosters social exclusion.

Moreover, empirical results further indicate the duo Culture-Indifference is evident in the case study region. The Garifuna culture shares its music and foods via markets, but besides this point of contact, few relations exist across cultural groups. A de-facto segregated society emerges, in which the bulk of the population peacefully co-exists with relatively few conflicts and limited coordination. They do so within a context of mutual distrust and indifference across cultural barriers. Thus, the drivers Culture-Indifference lead to a form of multicultural peaceful co-existence, such as that discussed by Kukathas (1998). This social phenomenon needs further research, as countries with important multi-cultural populations - including those currently experiencing social disintegration - could benefit by moving towards a politics of inter-ethnic co-existence [26]. As it is a form that entails minimal interaction, it may be less than ideal for societies striving for forms of co-existence such as 'integration', a 'melting pot', or 'multiculturalism'.

Table 8. The proposed new geography of governance network theories

\begin{tabular}{|c|c|c|c|}
\hline \multirow{2}{*}{\multicolumn{2}{|c|}{$\begin{array}{c}\text { DRIVERS } \\
\text { Analytical distinction } \\
\text { Issue }\end{array}$}} & \multicolumn{2}{|c|}{$\begin{array}{c}\text { Social Drivers } \\
\text { driving forces } \\
\text { for social action } \\
\end{array}$} \\
\hline & & Calculation & Culture \\
\hline \multirow{3}{*}{$\begin{array}{l}\text { Defining } \\
\text { features } \\
\text { of } \\
\text { societal } \\
\text { Governan } \\
\text { ce }\end{array}$} & Conflict & $\begin{array}{c}\text { Interdependency } \\
\text { Theory } \\
{[5,6]}\end{array}$ & $\begin{array}{c}\text { Governmentality } \\
\text { Theory } \\
{[7,8]}\end{array}$ \\
\hline & Coordination & $\begin{array}{c}\text { Governability } \\
\text { Theory } \\
{[9,10]}\end{array}$ & $\begin{array}{c}\text { Integration } \\
\text { Theory } \\
{[11,12]}\end{array}$ \\
\hline & Indifference & $\begin{array}{l}\text { Social } \\
\text { Exclusion } \\
\text { Theory } \\
{[25,27]}\end{array}$ & $\begin{array}{l}\text { Multi-Cultural } \\
\text { Peaceful Co- } \\
\text { existence [28] }\end{array}$ \\
\hline
\end{tabular}

Note: Prepared based on the four governance network theories given in Table 1 , but accounting for indifference as a form of societal governance.

\section{CONCLUSIONS}

Empirical findings indicate that the drivers (Calculation, Culture, Conflict, and Coordination) that underpin the theoretical framework for governance networks are present in the study area (Table 1). However, the findings also suggest that indifference, as a form of societal governance, is also present in the research site and is a driver unexplored in the existing framework. Thus, the network governance theory as mapped by Sorensen and Torfing can be strengthened by the incorporation of this form of societal governance.

Specifically, it is suggested that the governance network theoretical framework be revised to include indifference along with conflict and coordination as the defining features of societal governance (Table 8). This addition to the theoretical mapping of the governance terrain allows for the investigation of the two new sets of drivers outlined and empirically supported above: Calculation-Indifference and CultureIndifference.

Calculation-Indifference provides grounding to further understand social exclusion theory and how network operations can foment such exclusion. Meanwhile, the driver Culture - Indifference advances the understanding of Multicultural Peaceful Co-existence or at least a form of such co-existence that rests on minimal interactions across groups.
Last but not least, it should be recognized that indifference can be seen normatively and assessed against broader criteria of accountable government, human well-being, and ecological integrity; all principles set out as desirable norms. Indifference, against these standards, is a societally irresponsible form of management. Recall that it has been reported that in Germany an increasing number of families and children live in poverty as a result of political and economic indifference [24]. Likewise, in Britain, social exclusion processes have been identified as an important phenomenon that causes economic hardship and incremental poverty [27]. Furthermore, it has been suggested that in the European zone, the last ten years have resulted in widespread growth of social exclusion [29], with new forms of social exclusion present in societies and cities worldwide such as in the global north, global south, and global east $[30,31]$.

The revised theoretical framework for network governance, as shown in Table 8, includes indifference as a societal governance driver. The revised framework better accounts for governance dynamics observed in the fieldwork, as generated through this research. It is a theoretical platform that could prove useful in improving the efficiency and general operations of diverse governance networks, particularly with special reference to countries where patronage politics has a predatory control over a majority of resources.

\section{ACKNOWLEDGMENTS}

This research was made possible thanks to the financial support of the FQRSC (Fonds de Recherche du Quebec Société et Culture), IDRC (International Development Research Center), the Association of AUCC/CIDA (Sustainable tourism project-Honduras), and the School of Urban Planning, McGill University, Montreal, Canada. Special thanks are provided to Professors Lisa Bornstein and David Brown for the multiple revisions and comments provided during the preparation of this article. This research was also made possible thanks to the excellent health care provided to the author by Dr. David Small and Dr. Maurice Anidjar of the Jewish General Hospital, Montreal.

\section{REFERENCES}

[1] Lusthaus, C., Garven, K., Grandi, S. (2010). Chapter 4: Evaluating partnerships in the not for profit sector. In: Anderson G, editor. Shaping International Evaluation - A 30 Year Journey. Montreal, Canada: Universalia Management Group, pp. 75-112.

[2] Alvarado, R.E., Bornstein, L.M. (2018). Assessing the effectiveness of water and sanitation sector governance networks in developing countries: A policy analysis framework. International Journal of Sustainable Development and Planning, 13(3): 382-393. http://dx.doi.org/10.2495/SDP-V13-N3-382-393

[3] Ozturk, E., Eraydin, A. (2009). Environmental governance for sustainable tourism development: Collaborative networks and organisation building in the Antalya tourism region. Tourism Management, 31(1): 113-124.

http://dx.doi.org/10.1016/j.tourman.2009.01.002

[4] Hirst, P. (2000). Democracy and Governance. In: Pierre J, editor. Debating Governance. Oxford: Oxford Press, p. 
251.

[5] Rhodes, R. (1997). Understanding Governance Policy Networks, Governance, Reflexivity and Accountability. Maidenhead: Open University Press.

[6] Jessop, B. (2008). The rise of governance and the risks of failure: The case of economic development. International Social Science Journal, 50(155): 29-45. http://dx.doi.org/10.1111/1468-2451.00107

[7] Rose, N., Miller, P. (1992). Political Power beyond the State: Problematics of Government. The British Journal of Sociology, 43(2): 173-205. http://dx.doi.org/10.2307/591464

[8] Lemke, T. (2007). An indigestible meal? Foucault, governmentality and state theory. Distinktion: Scandinavian Journal of Social Theory.

[9] Scharpf, F.W. (1994). Games real actors could play: Positive and negative coordination in embedded negotiations. Journal of Theoretical Politics, 6(1): 27-53. http://doi.org/10.1177/0951692894006001002

[10] Kooiman, J. (2000). Societal Governance: Levels, Modes, and Orders of Social-Political Interactions. In: Pierre J, editor. Debating Governance. Oxford: Oxford University Press.

[11] DiMaggio, P.J., Powell, W.W. (1983). The iron cage revisited: Institutional isomorphism and collective rationality in organizational fields. American Sociological Review, 48(2): 147-160. http://doi.org/10.2307/2095101

[12] March, J.G., Olsen, J.P. (1995). Democratic Governance. New York: The Free Press.

[13] Sorensen, E., Torfing, J. (2007). Introduction: Governance Network Research: Toward a Second Generation. In: Sorensen E, Torfing J, Editors. Theories of democratic network governance. New York: Palgrave Macmillan.

[14] Sorensen, E., Torfing, J. (2007). Theoretical approaches to democratic network governance. Theories of democratic network governance. New York: Palgrave Macmillan, p. 356.

[15] Torfing, J., Sørensen, E. (2014). The European debate on governance networks: Towards a new and viable paradigm? Policy and Society, 33(4): 329-344. http://dx.doi.org/10.1016/j.polsoc.2014.10.003

[16] INYPSA. (2012). Plan de Ordenamiento Territorial Municipio de Tela. Proyecto de Gestión Sostenible de Recursos Naturales y Cuencas del Corredor Biológico Mesoamericano en el Atlántico Hondureño (PROCORREDOR). https://www.pgrdcopeco.gob.hn/wp-content/uploads/2019/07/PMGRTela-.pdf.

[17] Dulitzky, A.E. (2005). A region in denial: Racial discrimination and racism in Latin America. In: Neither Enemies nor Friends, pp. 39-59. http://doi.org/10.1057/9781403982636_2

[18] Herbold, R.J. (2004). The Fiefdom Syndrome - The turf battles that undermine careers and companies and how to overcome them. United States of America: A Currency
Book published by Doubleday a division of Random House Inc.

[19] Altschuler, D. (2013). How patronage politics undermines parental participation and accountability. Community managed schools in Honduras and Guatemala. Comparative Education Review, 57(1): 11744. http://doi.org/10.1086/667963

[20] Altschuler, D. (2013). Community managed schools in Honduras and Guatemala. Comparative Education Review, 57(1): 117-144. http://doi.org/10.1086/667963

[21] Blunt, P., Turner, M., Lindroth, H. (2012). Patronage, service delivery, and social justice in Indonesia. International Journal of Public Administration, 35(3): 214-220. http://doi.org/10.1080/01900692.2011.641050

[22] Ryan, R. (2008). The Mega Tourism Industry Threatens Garifuna Villages in Honduras Triunfo de la Cruz, Honduras2008. http://garifuna.com/\#formation.

[23] Honduras Accompaniment Project. Highs and lows in the struggle for land in Triunfo de la Cruz 2011. http://hondurasaccompanimentproject.wordpress.com/2 011/11/18/highs-and-lows-in-the-struggle-for-land-intriunfo-de-la-cruz/.

[24] Iturburo, M. Informe Honduras. 2009 Marzo 2009. In: Barometro de la Profesionalizacion de los servicios civiles de Centroamerica y Republica Dominicana [Internet]. Washington; [126-56]. https://servicioprofesionaldecarreracomparadofcpys.file s.wordpress.com/2012/09/barc3b3metro-de-laprofesionalizacic $3 \mathrm{~b} 3 \mathrm{n}$-centroc $3 \mathrm{a} 1 \mathrm{merica}$.pdf.

[25] Mierendorff, J. (1999). Childhood Social Exclusion Children's Situation and Social Exclusion in Germany http://www.oecd.org/edu/school/1856955.pdf.

[26] Mathieson, J., Popay, J., Enoch, E., Escorel, S. (2008). Social exclusion meaning, measurement and experience and links to health inequalities a review of literature. WHO Social Exclusion Knowledge Network Background Paper 1.

[27] Roth, K. (2001). Toward 'Politics of Interethnic Coexistence'. Europe: Cultural Construction and Reality, p. 37.

[28] Townsend, P. (1997). Redistribution: the strategic alternative to privatisation. In: Britain Divided: The Growth of Social Exclusion in the 1980s and 1990s. London: CPAG.

[29] Kukathas, C. (1998). Liberalism and Multiculturalism: The Politics of Indifference. Political Theory, 26(5): 68699. https://www.jstor.org/stable/191768.

[30] Hvinden, B., Halvorsen, R. (2012). Political implications of the current debate on poverty, deprivation and social exclusion in Europe - What guidance do scholarly perspectives and conceptualisations offer? http://coperesearch.eu/wpcontent/uploads/2012/04/Paper_Political_implications.p df: Carl von Ossietzky Universität Oldenburg (CETRO).

[31] Miraftab, F., Wilson, D., Salo, K. (2015). Cities and Inequalities in a Global and Neoliberal World: Routledge. 